\title{
O SUJEITO NO CONHECIMENTO. SOBRE FERNANDO GIL
}

\author{
Paulo Tunhas \\ Universidade do Porto \\ Instituto de Filosofia
}

Num texto publicado postumamente, que resume o seu plano para o livro que deveria suceder a $A$ convicção, Fernando Gil escreve que lhe interessa, nesse livro a vir, "reconduzir o objeto e a objetividade aos processos que os constituem". ${ }^{1}$ O livro - que conteria uma discussão do processo de espacialização enquanto atividade conducente à "constituição do objeto e da

1 Uma primeira versão, muito reduzida, deste texto, serviu de base à apresentação do livro A conviç̧ão (Porto: Campo das Letras, 2013), na Livraria Bulhosa, Lisboa, outubro de 2003, e foi publicada na revista Análise, série II, n. ${ }^{\circ} 1$, 2006, pp. 155-164, sob o título "Da crença à convicção". Versões mais desenvolvidas foram apresentadas no seminário "Racionalidade, desejo, crença", da Prof. Sofia Miguéns, FLUP, julho de 2003; na "Jornada de Filosofia" da Universidade da Beira Interior, a convite do Prof. Rui Bertrand Romão, maio de 2005; e no colóquio "A fundación da soberanía democrática en la filosofia política moderna" (Universidade de Santiago de Compostela, outubro de 2006). O presente texto desenvolve a apresentação feita num ciclo de seminários sobre o pensamento de Fernando Gil que, a convite do Prof. Renato Lessa, dirigi no Instituto Universitário de Pesquisas do Rio de Janeiro (IUPERJ), de abril a agosto de 2006. Este estudo enquadra-se numa série de trabalhos dedicados ao pensamento de Fernando Gil. Permito-me indicá-los: "Prendre l'évidence au sérieux". Critique, 559 (Paris, 1993): 847-859 (versão portuguesa: "Tomar a evidência a sério". In: Fernando Gil, Modos da evidência. Lisboa: Imprensa Nacional-Casa da Moeda, 1998, pp. 341-353); "Fernando Gil: um convite à leitura". Atlântico, 14 (2006): 60-63; "A filosofia levada a sério: o seminário". Diacritica, 20(2) (Universidade do Minho, Braga, 2006): 201-206; O Essencial sobre Fernando Gil. Lisboa: Imprensa Nacional-Casa da Moeda, 2007; "Fernando Gil e a controvérsia". Revista portuguesa da história do livro, 19 (Lisboa, 2007): 285-310; "Verdade e imaginação em Mimésis e negação". In: António Braz Teixeira (Org.), Homenagem a Fernando Gil. Lisboa: Imprensa Nacional-Casa da Moeda, 2008, pp. 43-74; "Colóquio Fernando Gil”. Revista Portuguesa de Filosofia, 63(1-3): 743-746; "A recusa da ideologia”. In: Maria Filomena Molder (Org.), Paisagens dos confins. Fernando Gil, Lisboa: Edições Vendaval, 2009, pp. 191-204. 
objetividade", 2 encetada a partir de Ding und Raum, de Husserl ${ }^{3}$ - deveria ser dedicado à análise da "verdade da evidência" e do "saber da convicção", isto é, dos correlatos objectivos dos temas dos seus dois livros anteriores: o Tratado da evidência e $A$ convicção, justamente. Mas já nesses livros encontramos o movimento de recondução ao mais originário que é um traço distintivo do pensamento final de Fernando Gil.

No Tratado, esse retorno ao originário é sobretudo operado através de uma articulação de Husserl com Freud, enquanto que Fichte - e valeria a pena interrogar com profundidade a modalidade particular da relação de Fernando Gil com a história da filosofia, o modo como os autores nele regressam, investidos de uma atualidade inesperada - é talvez a referência fundamental de $A$ convicção. Mas trata-se de um Fichte que se revela em consonância com vários temas husserlianos.

É de $A$ Conviç̧ão que falarei aqui. A presença de Husserl é subliminar, mas um ouvido atento à fenomenologia saberá, sem dúvida, escutá-la. E é bom que assim seja, porque $A$ convicção supõe a investigação anterior sobre a evidência, que, como disse, se encontra fortemente marcada pela fenomenologia. Fernando Gil encontrava-se, de resto, próximo de autores como Roderick Chisholm e, sobretudo, Hector-Neri Castañeda, que sabiam fazer conviver problemáticas "analíticas" e "fenomenológicas". 4

$A$ convicção é um livro que alia vários temas, regidos por um fio condutor poderoso. Certamente que múltiplos autores da tradição - Platão, Aristóteles, Anselmo, Bodin, Descartes, Hobbes, Espinosa, Kant, Fichte, Wittgenstein - são convocados - bem como alguns, talvez mais marginais, mas fundamentais para Fernando Gil, tais como René Thom e Hermann Weyl, ou mesmo Fred Dretske, Herbert Hart, Hans Kelsen e Carl Schmitt -, mas a sua linguagem técnica aparece investida de conteúdos semânticos que não diferem substancialmente dos da linguagem comum. O que é, diga-se de passagem, ótimo, e facilita grandemente a leitura do livro, que é complexo. Nesta análise, deixarei de lado certas discussões empreendidas por Fernando Gil, como por exemplo aquelas que versam sobre o argumento ontológico de Santo Anselmo, a teoria da soberania de Jean Bodin ou o intuitus cartesiano: ou melhor, referi-las-ei apenas na estrita medida do contexto das teses de Fernando Gil.

2 "Objeto e objectividade". In: Maria Filomena Molder (Org.), Paisagens dos confins. Fernando Gil, Lisboa: Edições Vendaval, 2009, pp. 223-226.

3 "Objeto e objetividade", cit., p. 226.++

${ }^{4}$ Cf., por exemplo, Roderick M. Chisholm, Person and Object. A Metaphysical Study. La Salle, Illinois: Open Court, 1976; e Hector-Neri Castañeda, The Phenomeno-Logic of the I. Essays on Self-Consciousness, Bloomington; Indiana University Press, 1999. 
Comecemos pela tese mais geral de $A$ convicção. Há uma relação entre o sujeito e a inteligibilidade do conhecimento, a inteligibilidade dá-se no sujeito. ${ }^{5} \mathrm{O}$ que significa isto? Significa que a inteligibilidade é o produto de uma atividade multiforme do espírito. ${ }^{6}$ Lidamos, portanto, com o lugar do sujeito e da ação deste no conhecimento. Sujeito, atividade, inteligibilidade fazem, como se diz em francês, sistema, implicam-se reciprocamente. Não há inteligibilidade sem uma atividade do sujeito: "A crença, a intuição, as práticas cognitivas relevam do sujeito". ${ }^{7}$ Este é um ponto importante, porque um dos aspetos mais notórios do trabalho de Fernando Gil - pelo menos desde o Tratado da evidência - foi justamente o de reintroduzir o sujeito em epistemologia, isto é, de mostrar que o entendimento conveniente dos saberes obriga à consideração do papel desempenhado pelo indivíduo na sua construção.

Dito de outra maneira: a boa análise do conhecimento, o bom inquérito sobre a inteligibilidade - e a questão da inteligibilidade é uma das questões mais propriamente suas que a filosofia põe aos saberes ${ }^{8}-$ deve constituir-se ao mesmo tempo como uma reflexão sobre aquilo que é da ordem do epistemológico (da relação do saber com a realidade) e sobre aquilo que releva do epistémico (da relação do sujeito com o seu saber). ${ }^{9}$ Trata-se de um par fundamental no pensamento de Fernando Gil. O epistemológico e o epistémico "implicam-se mutuamente". ${ }^{10}$ As duas modalidades (onto-epistemológica e fenomenológica) do intuitus cartesiano, ${ }^{11}$ ou os dois aspetos do noûs aristotélico ${ }^{12}$ - referir-me-ei ao intuitus e ao noûs mais tarde - podem servir como emblemas destes dois pontos de vista. A lógica da verdade - a lógica do conhecimento - e a lógica epistémica - a lógica da crença - são solidárias: "A lógica epistémica decalca-se sobre a lógica da verdade". ${ }^{13}$ A crença - Fernando Gil recupera uma lição de Hermann Weyl a propósito de um progresso de Fichte relativamente a Kant - não começa apenas com os problemas de Deus, da liberdade e da imortalidade: ela encontra-se imediatamente presente logo que a questão do saber se coloca. ${ }^{14} \mathrm{Em}$ termos kantianos: o problema da crença

5 A convicção, p. 13.

6 A convicçâo, p. 14.

7 A convicção, p. 23.

8 Ela articula-se com a disjunção entre sentido e verdade encetada pela cisão pós-galileana, um tema central no pensamento de Fernando Gil. $C f$., por exemplo, Mediações. Lisboa: Imprensa Nacional- Casa da Moeda, 2001, pp. 333 e ss.

9 A convicção, p. 14.

${ }^{10}$ A convicção, p. 156. Sobre o par epistémico/epistemológico, cf. A convicção, p. 180.

"A convicção, pp. 69 e ss.

${ }^{12}$ A convicçâo, pp. 155 e ss.

${ }^{13}$ A convicção, p. 178.

${ }^{14}$ A conviç̧ão, p. 45 (nota 17). 
não se põe apenas quando lidamos com matérias insuscetíveis de conhecimento no sentido forte, e que apenas podem ser pensadas, coloca-se já com realidades que podem ser conhecidas. (A distinção kantiana entre "conhecer" e "pensar" refere-se, como se sabe, respetivamente aos objetos da Analítica e da Dialética da Crítica da razão pura.) Não há maneira de afrontarmos o velho problema da racionalidade sem ter em conta a importância decisiva da experiência da crença. "Opor uma crença que se subtrai à exigência da prova a uma racionalidade que satisfaz os critérios do rigor" 15 é declaradamente insuficiente. $O$ bom percurso é aquele que nos leva a procurar determinar o entrelaçamento da crença e da racionalidade, o jogo entre a prova e certas crenças básicas que a dispensam (a crença na existência do mundo, por exemplo). $\mathrm{O}$ inquérito sobre a inteligibilidade tem forçosamente de passar por aí. O que implica igualmente que nos debrucemos sobre o desejo. A crença, com efeito, supõe o desejo, "um sujeito de desejo e de vontade". 16 "Acreditar é obra da alma desejante". ${ }^{17} \mathrm{O}$ que significa que não se pode acreditar sem se desejar. $\mathrm{E}$ a crença tem um objeto preferencial, o singular: "Em todos os casos, o existente singular é o molde da identidade e da evidência, a montante do saber e da prova". ${ }^{18}$

A inteligibilidade - tese decisiva e forte, consonante com os trabalhos de René Thom ${ }^{19}$ - é, em última análise, pré-linguística, a atividade do espírito assenta sobre bases pré-linguísticas: "a inteligibilidade é um dado préconceptual, pré-linguístico". ${ }^{20}$ A crença também: "A crença é uma disposição não discursiva". ${ }^{21}$ Tal como a convicção (voltarei mais tarde à distinção entre crença e convicção, um dos aspetos mais importantes da obra): "Sentimento do verdadeiro, a convicção não é discursiva". ${ }^{22}$ "Se a linguagem é pública, a cognição é privada, ela continua a ser tarefa do espírito". ${ }^{23}$ Os estratos últimos do sujeito são eles próprios pré-linguísticos: "Nem a consciência nem a experiência de si, em nenhuma das suas modalidades, são da ordem da represen-

15 A convicção, p. 14.

16 A convicção, p. 23.

17 A convicção, p. 142.

18 A convicção, p. 200.

19 Sobre René Thom, $c f$. em particular $A$ convicção, pp. 105 e ss. Trata-se de uma referência constante em Fernando Gil. Um capitulo de Modos da evidência ("Que é compreender?") é-lhe inteiramente dedicado (Modos da evidencia, Lisboa; Imprensa Nacional-Casa da Moeda, 1998, pp. 127 e ss.). Mas tanto o Tratado da evidência como Mimésis e negação evidenciam a dívida e o reconhecimento de Fernando Gil para com Thom.

${ }^{20}$ A convicção, p. 110.

21 A convicção, p. 143.

22 A convicção, p. 180.

23 A convicção, p. 14. 
tação e da linguagem". ${ }^{24}$ Essa arcaicidade pré-linguística repercute-se ainda em certos saberes. A matemática, por exemplo, é, como queria Brouwer, "uma atividade do intelecto sem linguagem". ${ }^{25}$ Afirmar o carácter pré-linguístico da inteligibilidade, da crença e da convicção é, entre outras coisas, buscar um estrato profundo que dê razão do não-arbitrário do nosso conhecimento. Não se trata de um exercício de dogmatismo. O carácter pré-linguístico da crença depreende-se de investigações sobre, por exemplo, a crença animal - de que Fernando Gil se ocupa, e a que me referirei adiante - bem como da já mencionada teorização da matemática intuicionista. Para mais, e por estranho que pareça a ouvidos contemporâneos, afirmar o carácter originariamente pré-linguístico da crença é bem menos contra-intuitivo do que fazê-la depender estritamente da representação e da linguagem. (Ou, antes disso, da res cogitans cartesiana: e aqui haveria que traçar a história - que Fernando Gil não enceta, mas que seria sem dúvida instrutiva - da rejeição da "crença animal" a partir de Descartes).

Encontramo-nos assim, a partir da questão da inteligibilidade, no seio do próprio problema da compreensão, que remete para o problema do sentido do conhecimento para o sujeito. ${ }^{26} \mathrm{~A}$ compreensão é o quale do conhecimento: "«como é», para mim, conhecer?". ${ }^{27}$ Compreender, dito de outra maneira, é conhecer sob o modo do sujeito. Nesse sentido, a compreensão distingue-se - pelo menos num primeiro plano - da explicação: "A explicação assenta na objetividade do sentido, mas a compreensão, a satisfação do espírito intrínseca à explicação, permanece obrigatoriamente antropomórfica". ${ }^{28}$ Quer isto dizer - e assim vemos que o primeiro plano da oposição compreensão/explicação tende a esbater-se - que a explicação, para ser eficaz, deve permitir que o sentido objetivo possa ser subjetivamente apropriável, isto é, compreendido, produzindo um contentamento intelectual que é o seu corolário natural. ${ }^{29}$ ("Antropomórfico" remete aqui para a obra de René Thom. A epígrafe de $A$ convicção é uma citação deste: "Pode reconhecer-se outra coisa que não si mesmo?") Referindo-se a Platão e ao diagrama da linha dividida da República, do qual oferece uma profunda análise, Fernando Gil escreve que a "theôria [...] não é um modo novo de conhecimento, mas a apropriação subjetiva do

\footnotetext{
24 A conviç̧ão, p. 27.

25 A conviç̧ão, p. 53.

26 A conviç̧ão, p. 15.

27 A convicção, p. 27. Como se sabe, o problema da experiência qualitativa irredutível dos indivíduos foi uma questão em que Thomas Nagel insistiu poderosamente.

${ }^{28}$ A conviç̧ão, pp. 107-108.

29 Sublinho que o tema da "satisfação do espírito" é um tema recorrente em Fernando Gil.
} 
saber"; "theôrein é um ato subjetivo e intransmissível". ${ }^{30}$ Por outras palavras: que me é próprio e do qual não posso fazer a economia se quero saber alguma coisa. "A intelecção do verdadeiro no ato de pensar implica simultaneamente a sua posse". ${ }^{11}$ E o mesmo se dirá do noûs aristotélico, que, tal como o Bem platónico, nos concede inteligibilidade e uma apropriação, uma posse, do conhecido: "ele designa uma instância subjetiva que, ao apreender os princípios, se confunde com eles. O sujeito faz sua a verdade que intui na demonstração". ${ }^{32}$ $\mathrm{O}$ noûs em ato "é idêntico aos seus próprios objetos". ${ }^{33} \mathrm{~A}$ apropriação perfaz-se assim numa quase identidade entre o sujeito cognoscente e o conhecido (algo que, de uma forma ligeiramente diferente, se encontra já em Mimésis e negação). ${ }^{34}$ Apropriação e identificação são produto de uma construção, isto é, de uma atividade: "O ato de conhecer é obra de um sujeito, ele acompanha-se pela intuição do verdadeiro que constrói" ${ }^{35}$

A centralidade do problema da compreensão conduz naturalmente a um reexame do já mencionado conceito de explicação, a uma sua articulação com a intuição. No domínio do conhecimento científico - e, bem vistas as coisas, em qualquer outro domínio -, "a explicação deve culminar na intuição para produzir a convicção". ${ }^{36}$ Uma lição que vem já de Kant: "todo o pensamento tem como fim a intuição" ${ }^{37}$ Fixemos bem esta tese: a intuição permanece uma condição sine qua non da convicção, e a boa explicação tem por fim dirigir-se a ambas. Claro que as crenças se podem travestir em intuições ${ }^{38}$ - falsas intuições - mas isso não impede que uma explicação que não engendre a conviç̧ão - ou que a ela não nos reconduza - não seja uma boa explicação. Tratar-se-á de uma exigência excessivamente forte, que raras vezes encontra aplicação? Um requisito hiperbólico? Num certo sentido, sim; num outro não. Sim, porque na maior parte das vezes nos contentamos com explicações cujo processo de construção, por obscuridade intrínseca deste, ou ignorância ou preguiça nossas, não conseguimos apurar - a luta de classes é o motor da história, por exemplo. Não, porque o que interessa realmente, do ponto de vista filosófico - isto é, a partir de uma investigação sobre a inteligibilidade -, é determinar os casos mais radicais, a partir dos quais as modalidades mais fracas possam

\footnotetext{
${ }^{30}$ A convicção, p. 103. Cf., em geral, A convicção, pp. 102 e ss.

31 A convicção, p. 185.

32 A convicção, p. 162.

33 A convicção, p. 163.

${ }^{34}$ Mimésis e negação, Lisboa: Imprensa Nacinal-Casa da Moeda, 1984, Cap. I.

${ }^{35}$ A conviç̧ão, p. 81.

${ }^{36}$ A convicção, p. 14.

37 A convicção, p. 139.

38 A convicção, p. 169.
} 
ser deduzidas. Além disso, de uma forma sem dúvida imprecisa, todos nós buscamos, por vezes, convicções fortes, intuições indesmentíveis. Não é por exemplo indiferente, para um apaixonado, ter ou não ter a convicção, no sentido forte, de que a outra pessoa o ama - ou para um doente em estado grave, de que a cura se vai produzir. Através deste tipo de questões, Fernando Gil reencontra alguns dos autores que não temeram associar convicção e inteligibilidade: Espinosa, Fichte, Wittgenstein. São, sem dúvida, personagens centrais deste livro.

O que está aqui em jogo é bem uma metafísica do conhecimento. ${ }^{39}$ A reintrodução do sujeito em epistemologia desemboca naturalmente aí. Ela articula-se, bem entendido, com os ensinamentos das epistemologias, mas o seu estatuto é, no fundo, outro. Quase se poderia dizer que ela é epistemologicamente neutra, no sentido em que se situa aquém das controvérsias epistemológicas habituais. Situa-se aquém, por exemplo, de um debate sobre o estatuto das provas em ciências (tema sobre o qual Fernando Gil se debruçou noutras obras, nomeadamente em Provas). ${ }^{40}$ Mas também é verdade que, ao dizer isto, se simplifica um pouco: porque um inquérito sobre a convicção lida forçosamente com a relação do sujeito com as provas, quanto mais não seja para mostrar que a convicção (e, a fortiori, a crença) não é redutível à prova. Apenas mais uma palavra sobre o que se deve entender por "metafísica do conhecimento". Em parte, sem dúvida, uma reflexão transcendental, à maneira kantiana, sobre as condições de possibilidade do conhecimento. Mas - e aqui, se não há rutura com Kant, há pelo menos uma inflexão fichteana da leitura deste - ligando de forma incisiva o epistémico ao epistemológico. $\mathrm{O}$ que se segue tornará, creio, isto mais claro.

Comecemos a clarificação atendendo a um ponto essencial. A convicção põe em jogo dois grupos de conceitos, cuja relação é, num certo sentido, o objeto principal deste livro - e, por isso, a eles voltarei várias vezes. Primeiro grupo: fundação, prática, intuição; segundo grupo: fundamento, imaginação realizante, crença. ${ }^{41}$ Antes de entrar em detalhes, uma consideração muito geral. Fernando Gil entende por fundação o processo, levado a cabo por um sujeito, que engendra, através da prática, da efetuação, a recondução da explicação à intuição: a demonstração matemática é um exemplo - o sujeito que a produz, ou a reproduz, produz uma série de operações que, no ato, lhe aparecem como vivas, transparentes, inteligíveis. E, por fundamento, a posição de um objeto sem que esse objeto surja transparente no ato da sua afirmação, da

\footnotetext{
${ }^{39}$ A convicção, p. 15.

${ }^{40}$ Provas. Lisboa: Imprensa Nacional-Casa da Moeda, 1986.

41 A convicção, p. 16.
} 
sua posição, isto é, em última análise, sem que a explicação conduza à intuição, a uma presentificação indiscutível: a prova ontológica da existência de Deus, por exemplo. A crença liga-se assim ao fundamento, a convicção à fundação. A crença não se dá através de uma série de operações interconectadas do espírito, transparentes a este, e - como vimos atrás, a propósito da compreensão produzindo objetos que com ele fusionam. A convicção, atingida através da fundação, sim. A "fundação leva à evidência efetiva da convicção". ${ }^{42}$ À crença no fundamento - uma crença alucinatória, ${ }^{43}$ na medida em que o espírito, pelo seu movimento próprio, alucina o infinito no singular - dá Fernando Gil o nome de pensamento soberano, ${ }^{44}$ operatório no quadro da teoria política - a conceção da soberania em Jean Bodin, "passagem ao limite da vontade transformada em potência abstrata" ${ }^{45}$-, da teologia - a prova anselmiana da existência de Deus no Proslogion, passagem da existência in intellectu à existência in r $e^{46}$ - e da teoria do conhecimento - os primeiros princípios aristotélicos. ${ }^{47} \mathrm{O}$ pensamento soberano - que se define sempre pela auto designação (é per se) e pela posição do incondicionado, ${ }^{48}$ pela ilimitação ${ }^{49}$ - constitui-se como uma "alucinação do fundamento", ${ }^{50}$ que é, vê-lo-emos já a seguir, uma ocultação da fundação. A alucinação é, de facto, fundamental. $\mathrm{O}$ "salto alucinatório" 51 na origem da passagem da fundação para o fundamento encontra-se nos domínios que acima apontei, e de um modo idêntico. Trata-se sempre de projetar o infinito - um infinito atual, não apenas potencial - no existente. De ver o existente como inteiramente autárquico, causa de si mesmo, e incondicionado. "A soberania é causa sui. Tal como o Deus de Anselmo e os primeiros princípios dos Segundos analíticos, ela dá-se por si e define-se pelo seu incondicionado". ${ }^{52}$ Tudo isto remete para a vontade. Tomemos o exemplo da soberania. Relativamente expulsa da ordem jurídica por Kelsen, ${ }^{53}$ a vontade é aceite de modo exorbitante por Carl Schmitt. ${ }^{54}$ Ela "intervém na crença" 55

\footnotetext{
42 A convicção, p. 173.

${ }^{43}$ A convicção, pp. 137, 146, 173.

${ }^{44} A$ convicção, pp. 16,113 ss.

45 A convicção, p. 15. Sobre Bodin, cf. A convicção, pp. 113 e ss.

${ }^{46}$ Sobre Anselmo, $A$ convicção, pp. 137 e ss.

47 Sobre Aristóteles, $A$ convicção, pp. 155 e ss.

48 A convicção, pp. 95, 96, 130, 145, 166, 168.

49 A convicção, pp. 117 e ss.

${ }^{50}$ A convicção, p. 137.

51 A convicção, p. 63.

52 A convicção, p. 124.

53 A convicção, p. 124.

${ }^{54}$ A convicção, p. 127.

55 A convicção, p. 148.
} 
- quer dizer: determina-a por inteiro - e "alucina-se na soberania". 56 "A vontade encontra-se na raiz do fundamento". ${ }^{57}$ Com efeito, "todas as teorias da soberania se estabelecem sobre operações sobre a vontade". 58 "A soberania contém uma causalidade interna que se basta a si mesma e que reproduz a do querer". ${ }^{59}$ Mas, saltando do domínio do direito e da política para o do conhecimento, o mesmo vale: "os primeiros princípios aristotélicos testemunham igualmente uma causalidade autárquica ligada ao ato voluntário". ${ }^{60} \mathrm{Há}$, em geral, "uma auto designação fundadora que nenhuma outra instância pode regular", 61 uma auto designação vertiginosa, "próxima do sagrado", ${ }^{62}$ e essa auto designação - cujas aporias o Monologion de Anselmo, através da prova ontológica da existência de Deus, "exibe inauguralmente" 63 - acompanha-se de um fechamento em si: "a soberania não tem abertura", 64 "põe-se sem se referir a um exterior" ${ }^{65}$ A soberania "não reconhece a sua origem", ${ }^{66}$ ela busca "obliterar" a sua "dependência relativamente à vontade real" que a originou. ${ }^{67}$ A operação da construção é sublimada, o objeto é dado como uma realidade imediata. ${ }^{68}$ Dito de outra maneira: há uma ocultação da fundação pelo fundamento. É como se, face a uma crença reificada, petrificada, o processo que engendra efetivamente essa mesma crença deixasse de existir. Embora - vê-lo-emos mais adiante - essa ocultação seja sempre parcial. Diferentemente do pensamento soberano, a "auto posição da intuição intelectual", 69 movimento que leva à convicção, não é uma alucinação do fundamento: é um livre agir. ${ }^{70}$ Este ponto é particularmente importante: a convicção supõe um agir, ela $e$, num certo sentido, um agir. A "ação é o lugar da convicção"."11 Nada de petrificado: apenas uma sucessão de operações perfeitamente inte-

\footnotetext{
${ }^{56}$ A convicção, p. 127.

${ }^{57}$ A convicção, p. 166.

58 A convicção, p. 127. Sobre a dependência da soberania por relação à vontade, nomeadamente em Rousseau, $c f$. 127-9.

59 A convicção, p. 55.

${ }^{60}$ A convicção, p. 155.

${ }^{61}$ A convicção, p. 123.

62 A conviç̧ão, p. 127.

${ }^{63}$ A convicção, p. 144.

${ }^{64}$ A convicção, p. 123.

65 A convicção, p. 130.

${ }^{66}$ A convicção, p. 123.

${ }^{67}$ A convicção, p. 127.

68 "Imediato" não significa "direto". Cf. A conviç̧ão, p. 227, e nota 64.

${ }^{69}$ A convicção, p. 216.

70 A conviç̧ão, p. 218.

71 A conviç̧ão, p. 207.
} 
ligíveis, transparentes, para o sujeito. E encontramos aqui o par ideologia/verdade. Se a crença se refere, num certo sentido, à ideologia, a convicção relaciona-se com a verdade: ${ }^{72}$ embora, sem dúvida, ambas se interpenetrem. ${ }^{73} \mathrm{Ao}$ contrário da crença, a convicção (e o modelo por excelência da convicção é a convicção matemática, que se produz "no modo da evidência" ${ }^{74}$ ) conhece-se a si mesma - será esse um traço distintivo da verdade - "e dá-se de um só vez, no termo da demonstração". ${ }^{5}$ Observa-se aqui a importância do processo, do conjunto das operações, e a sua oposição a um modelo que realiza imediatamente, fazendo a economia de qualquer operação, de qualquer construção, caminhando imediatamente para posições maciças. "A crença poupa-se à determinação do objeto mediante operações de conhecimento [...] A convicção liga-se a um objeto fundado e reconhecido, a crença não espera pela sua construção, afirma a realidade do objeto. O real suposto substitui a construção cognitiva do objeto": Por isso, o fundamento aspira a uma "validade definitiva", enquanto a convicção busca antes uma "validação progressiva". ${ }^{77} \mathrm{~A}$ intuição, o intuitus das Regulae cartesianas, põe em jogo estes dois momentos, a partir de duas vertentes: uma, onto-epistemológica, baseada na intelecção (figura da crença e do fundamento); outra, fenomenológica, ligada à atividade do sujeito e baseada na compreensão (figura da convicção e da fundação).$^{78}$ Não há tempo para analisar aqui a profunda discussão que faz Fernando Gil do intuitus. Basta assinalar que a presença dos dois aspetos no mesmo conceito é prova suficiente de que crença e convicção, fundamento e fundação, ideologia e verdade, andam muitas vezes de mãos dadas, e, se bem que distinguíveis, podem perfeitamente conviver no pensamento.

A convicção é, como se deduz do que anteriormente foi dito, o produto de um sujeito. Mais precisamente, ela resulta do conjunto de atividades - de operações - que o sujeito realiza. O sujeito - o Eu - define-se, entre outras coisas, por uma adesão a si: "Se bem que des-substancializado, desunido, complexo, o Eu não se reduz a um postulado formal, a sua desconstrução não implica por isso a perda da adesão a si". 79 "Adesão a si" significa algo como uma suposição, que não posso esquivar, de que sou eu que ajo e que padeço.

72 A convicção, p. 18.

${ }^{73}$ A conviç̧ão, p. 16, 18.

${ }_{74}$ A convicção, p. 195. Cf. tb. A convicção, p. 193.

${ }^{75}$ A convicção, p. 194.

${ }^{76}$ A convicção, p. 91.

77 A convicção, p. 69.

78 A conviç̧ão, pp. 69 e ss.

79 A convicção, p. 24. Cf. tb., sobre esta questão, as páginas dedicadas à "certeza de si" em Wittgenstein, $A$ convicção, pp. 208 e ss. 
Adiro a mim: sou eu. Não posso acreditar que não sou eu, e que o Eu não dura. Se não acreditasse na duração do Eu, uma "duração indefinida" 80 - se não aderisse a mim - seria incapaz de agir. Ação, vida, e adesão a si encontram-se associadas. ${ }^{81} \mathrm{~A}$ adesão a si é "princípio de vida". ${ }^{22}$ (A adesão a si do sujeito desdobrar-se-á numa adesão aos objetos da crença, a que voltarei adiante.) Especificação suplementar: há um carácter qualitativo, não transmissível e não relacional das declinações do Eu, "portador da experiência própria", ${ }^{84}$ na primeira pessoa. ${ }^{85}$ Quer dizer: a experiência que cada um tem de si mesmo não é, em última análise, transmissível. Cada um transporta consigo, na primeira pessoa, essa experiência, mas ninguém se consegue dizer inteiramente a si mesmo a outra pessoa. Fernando Gil não se exprime assim, mas creio que esta formulação não lhe mereceria desaprovação. Ninguém consegue mesmo, dado o carácter público da linguagem, dizer-se inteiramente a si mesmo: mas cada um experimenta-se por inteiro a si, cada um sabe perfeitamente o que é ser si mesmo. Isto quanto à adesão a si. O caso da identidade pessoal ${ }^{86}$ é distinto. Esta, contrariamente ao agir e ao padecer, que se encontram no cerne da experiência pessoal, não se experimenta diretamente. E, por isso, a experiência de si é incapaz de a fundar - a identidade pessoal revela-se como "crença e abstração, crença numa abstração". 87 "A crença na permanência do eu difere da evidência da imanência do agir para o seu agente". ${ }^{88} \mathrm{E}$, por isso, os argumentos de Montaigne ou de Hume relativos à "permanência do eu" não se contornam facilmente. ${ }^{89}$ "A identidade pessoal esteia-se na crença na existência do eu (se é que ela não é simplesmente essa crença) que é crença na sua permanência (o transporte de uma mesma experiência no curso do tempo)"..$^{90}$ Mutatis mutandis, o mesmo valerá para certa conceção medieval da soberania - "A identidade da coroa revela-se do mesmo tipo da identidade do eu" 91 ou para o carácter inteligível segundo Kant, ou ainda para a vontade geral em Rousseau. ${ }^{92}$ Se quisermos voltar às categorias de há pouco, a identidade

\footnotetext{
80 A convicção, p. 24.

81 A convicção, p. 44.

${ }^{82}$ A convicção, p. 44.

${ }^{83}$ A convicção, pp. 23 e ss.

84 A convicção, pp. 24, 26, 33, 95.

${ }^{85}$ A convicção, pp. 13, 23, 26, 95.

${ }^{86}$ A convicção, pp. 23, 26.

87 A convicção, p. 39.

${ }^{88}$ A convicção, p. 39.

${ }^{89}$ A convicção, pp. 41-422.

${ }^{90}$ A convicção, p. 90.

91 A convicção, p. 113.

92 A convicção, p. 102.
} 
pessoal é a versão reificada (mas, é verdade, trata-se de uma reificação compulsiva) da adesão a si. Esta é um processo, enquanto que a identidade pessoal é uma posição absoluta que transcende a imanência do processo. Ainda de outra maneira: a identidade pessoal (fundamento) oculta a originária adesão a si (fundação).

A unidade do Eu - como coisa distinta da identidade pessoal, sua reificação compulsiva e inescapável - dá-se no agir e no sentimento, no "eu faço", e no "eu sinto". ${ }^{93} \mathrm{E}$, como vimos, na imanência. O Eu é "a permanência de uma forma que se vive como um sentir e um agir imanentes". ${ }^{94}$ Ele é, como se disse atrás, o quadro natural da inteligibilidade: " $A$ ação do sujeito é o quadro natural da inteligibilidade". ${ }^{55}$ Só posso, no limite, compreender aquilo que faço. Mas há mais: "As categorias normativas da inteligibilidade coincidem com as ações do Eu". ${ }^{96} \mathrm{O}$ que significa isto? Significa que a inteligibilidade se articula com a ação, que a ação é a condição de possibilidade da inteligibilidade. No fundo, a inteligibilidade é ação, ação pura, ação transparente ao sujeito. A confiança na ação repousa na duração (voltarei em breve às questões, essenciais, da confiança e da duração). Trata-se, para cada um, muito espinosianamente, de perseverar no seu ser: "Perseverar no seu ser traduz-se diretamente na vontade de crer na permanência do sujeito no tempo".97

Disse já que nos movíamos num estrato pré-linguístico. Cabe agora acrescentar: a consciência de si e a experiência subjetiva não são representações..$^{98}$ Dito de outra maneira: tal estrato - o estrato das crenças mais primitivas e mais fundamentais - é igualmente pré-representativo. "A crença dispensa a representação". ${ }^{99} \mathrm{Um}$ bom exemplo disso é a crença animal, que Fernando Gil analisa em parte através dos trabalhos de Fred Dretske. ${ }^{100}$ Não há aqui espaço para entrar na complexidade dos detalhes, mas, dando ao termo "representação" o sentido comum, que implica, de um modo ou outro, mediação conceptual ou linguística, a proposição segundo a qual a crença animal é não-representativa não parece poder levantar grandes problemas. Que existe crença animal parece ser um dado intuitivo da experiência: um cão acredita que o dono chega a casa a uma determinada hora, etc. Ponham-se as aspas que se quiser em torno de "acredita", que a suposição contrária - a que o cão não

\footnotetext{
93 A conviç̧ão, p. 27.

${ }^{94}$ A conviç̧ão, p. 27. Cf. tb. A convicção, p. 223.

95 A conviç̧ão, p. 107.

96 A convicção, p. 217.

97 A convicção, p. 44.

${ }^{98}$ A convicção, p. 27.

99 A convicção, p. 50. Cf. tb. A convicção, p. 31.

${ }^{100}$ A convicção, pp. 57-60.
} 
acredita que o dono vai chegar a casa a uma determinada hora, ou em qualquer outra coisa - é sempre mais contraintuitiva do que a outra. E o ónus da prova cabe, como Fernando Gil gostava sempre de lembrar, aos que defendem a hipótese mais contraintuitiva (e que podem ter, de resto, toda a razão do mundo: mas é preciso prová-la). Acrescente-se que o que é "intuitivo" ou não, não é inteiramente convencional (mas discuti-lo aqui envolveria caminhar por várias disciplinas, da biologia à antropologia e à sociologia, por isso faço de conta que não há problema). Voltemos à nossa questão. A crença humana prolonga naturalmente a crença animal: "Tal como o animal, o homem é naturalmente crente". ${ }^{101}$ Isto é: a sua disposição a acreditar é primeira por relação à sua disposição a duvidar. "A propensão a acreditar, efeito da seleção natural prolongada pela aprendizagem e a transmissão histórica converte-se em disposição que as práticas transformam em convicção pessoal". ${ }^{102}$ Tem-se portanto aqui uma cadeia que, para simplificar, vai da seleção natural à convicção pessoal, passando pelas práticas, que englobam os princípios de transmissão dos conhecimentos, os hábitos cognitivos. Por enquanto, basta dizer que as "práticas" designam, entre outras coisas, os procedimentos de construção do conhecimento. Resumindo, e voltando ao essencial, isto é, ao estrato mais primitivo: "A posição do mundo é um facto biológico, a dedução transcendental prolonga a seleção natural". ${ }^{103} \mathrm{O}$ que significa que o cognoscente prolonga o conhecido, que - por vias mais ou menos travessas, por caminhos mais ou menos ínvios - há uma afinidade entre o que expressa e o que é exprimido. Mais uma lição que se encontra já em Mimésis e negação. ${ }^{104}$ Essa afinidade manifesta-se no decalque do biológico pelo conceptual. "As raízes da certeza mergulham na vida animal e na história social da espécie". ${ }^{105}$ E o puro conceptual - o ceticismo, se se quiser, como a figura máxima que o puro conceptual tomou no leque das possibilidades filosóficas mais gerais (noto, no entanto, que Fernando Gil não discute a posição cética, pelo menos a pirrónica, em A convicção; Montaigne e Hume só são céticos, poder-se-ia dizer, por afinidade) - não pode eliminar a força profunda do estrato mais arcaico da psique: a "crença no mundo exterior é compulsiva". ${ }^{106}$ Tão compulsiva quanto aquela que se exprime na identidade pessoal. E, bem entendido, sujeita a objeções do mesmo tipo daquelas que a identidade pessoal suscita, e igualmente legítimas - e igualmente ineficazes no plano da vida.

\footnotetext{
101 A conviç̧ão, p. 206. Cf. tb. A convicção, p. 55.

102 A convicção, p. 211.

103 A convicção, p. 51.

104 Mimésis e negação, p. 96.

105 A conviç̧ão, p. 204.

${ }^{106}$ A convicção, p. 218. Cf. também, sobre a compulsão da crença, $A$ convicção, pp. 52, 147.
} 
O domínio do pré-representativo é igualmente o do pré-intencional. ${ }^{107}$ A crença é uma "atividade pré-intencional". ${ }^{108}$ Quer isto dizer que, ao nível mais profundo - e à maneira da "energia livre" freudiana - ela não se fixa em objetos determinados. É algo de difuso suscetível de tudo abarcar sem nada determinar inteiramente. Tal como, em parte, no verso de Camões que Fernando Gil um dia comentou: $O$ mundo todo abarco e nada aperto. ${ }^{109} \mathrm{~A}$ ação não é dirigida a nada em particular: é pura ação, atividade ininterrupta consubstancial ao Eu. A crença exprime-se através do sentimento e da tendência (conceitos fichteanos), que não são intencionais. ${ }^{110}$ 'No plano fenomenológico, o sentimento exprime a positividade irredutivel da sensação ou do sentimento do agir e do querer. Do ponto de vista do objeto, é um índice do Não-Eu". ${ }^{111}$ Em qualquer dos aspetos (fenomenológico e ontológico) o sentimento designa o percurso para um mundo aberto e indeterminado (se bem que determinável), prévio a qualquer atividade dirigida (intencional) de fixação. A tendência, por sua vez, paralelamente ao sentimento, significa o movimento "para fora de si mesmo" do Eu, um movimento que se dirige "para algo de desconhecido". ${ }^{112}$ "Pré-intencional" quer igualmente dizer: anterior à reflexão. ${ }^{113} \mathrm{~A}$ reflexão supõe que os obstáculos exteriores (o "mundo") se encontrem já determinados, ou, pelo menos, o exercício avançado da sua determinação. Ora, sentimento e tendência - os principais movimentos pré-intencionais do Eu, representando o estrato mais profundo da crença - são prévios à determinação do Não-Eu (embora sejam operatórios nela). A "pré-intencionalidade" releva de uma "atividade originária e sem objeto do espírito", ${ }^{114}$ uma "energia psíquica", ${ }_{115}$ que é, bem entendido, "inconsciente". ${ }^{116}$ A crença começa com o inconsciente.

Todo este estrato implica uma continuidade essencial. A reflexão sobre a continuidade é igualmente um dos temas recorrentes na obra de Fernando Gil: em Mimésis e negação, no Tratado da evidência, n'A convicção - e, bem entendido, nos seus vários escritos sobre Leibniz e sobre o pensamento morfológico. ${ }^{117} \mathrm{Em} A$ convicção, a continuidade aparece ligada sobretudo ao

\footnotetext{
107 Sobre a "esfera pré-intencional", $c f$. A convicção, pp. 82 e ss.

108 A conviç̧ão, p. 82 ss.

109 Acentos. Lisboa; Imprensa Nacional-Casa da Moeda, 2005, p. 255.

110 A convicção, p. 83.

111 A convicção, p. 83.

112 A convicção, p. 82.

113 A convicção, p. 83.

114 A convicção, p. 88 .

115 A convicção, p. 84

116 A convicção, pp. 82, 84 .

117 Cf., por exemplo, sobre Leibniz, Modos da evidência, pp. 101 e ss; Acentos, pp. 164 e ss; Mediações, pp. 85 ss. Sobre o pensamento morfológico, cf. Mediações, pp. 103 e ss., 315 e ss.
} 
tema da duração. "A posição de uma continuidade que forma uma unidade no tempo, como uma biografia, é um imperativo da vida". ${ }^{118} \mathrm{O}$ nome dessa continuidade é duração, e a vida pressupõe a duração $<$ Dauer, durée $>$, o sentimento de uma continuidade temporal que a vontade deve capturar: "cabe à vontade pura domesticar, por assim dizer, a duração". ${ }^{119}$ Três coisas a notar. Primeiro, o estrato pré-intencional, a dimensão mais arcaica, da crença, requer a continuidade - a continuidade liga-se ao carácter difuso e indeterminado da crença, que se pode aplicar a todo e qualquer objeto, sem se fixar em nenhum. A crença é polimorfa. Segundo, essa continuidade é concebida como duração, permanência, quer dizer, sob o modo temporal. Terceiro, cabe à vontade domesticar essa continuidade, o que significa instituí-la como unidade. É este último ponto que é aqui importante. A vontade, como vimos antes, "intervém na crença". E intervém, precisamente para a determinar, para a fixar (no caso do pensamento soberano - mas não só - alucinatoriamente). O exercício da vontade, no contexto que nos ocupa agora, é um exercício de domesticação da duração que visa conferir-lhe as características da unidade e da simplicidade, isto é, proceder à alucinação compulsiva da identidade pessoal.

Se a vontade tem por missão capturar, ou apreender, a continuidade - domesticá-la, para utilizar uma fórmula mais veemente -, e nomeadamente a continuidade transformada em duração, continuidade e duração são, a montante, um produto da imaginação. É a imaginação - que "não se separa da crença", tal como "a crença não se separa da imaginação": "A imaginação é crente, a crença imagina" 120 - que "fabrica a continuidade" ${ }^{121}$ e a duração. ${ }^{122}$ A imaginação é, assim, intrinsecamente criadora, tal como Kant, Fichte (e, num certo sentido, já Aristóteles, no De anima) o viram. Mas a referência principal de Fernando Gil neste livro é Fichte, que elabora aquela que é, sem dúvida, a versão mais radical da tese (mais radical mesmo do que a que Heidegger proporá no seu célebre estudo sobre Kant, e, sobretudo, mais operativa). E, com a continuidade, a imaginação produz igualmente a existência: "A imaginação é o operador oculto da existência". ${ }^{123}$ Dizer que a imaginação produz a existência é atribuir-lhe a mais originária das funções: a existência, na sua presença, não se dá imediatamente, ela é o produto da ação criadora da imaginação. A imaginação realiza. O "pensamento soberano" (inclusive em Aristóteles) servir-se-á da imaginação, e, ao mesmo tempo, ocultá-la-á.

\footnotetext{
118 A convicção, pp. 40-41. Sobre a continuidade, $c f$. igualmente $A$ convicção, p. 41.

119 A convicção, p. 229.

120 A convicção, p. 65.

121 A convicção, p. 65.

122 A convicção, p. 44.

123 A convicção, p. 69.
} 
Mas retornemos à continuidade, quer dizer: a algo que se oferece a jusante da imaginação criadora. É na continuidade, e apenas nela, que é possível a confiança. A confiança na ação repousa na duração, ${ }^{124}$ a continuidade satisfaz "uma necessidade, de algum modo transcendental, de confiança na ação empreendida". ${ }^{125}$ Se não disponho de uma continuidade, temporalmente concebida como duração, envolvendo as minhas ações e as dos outros, é-me impossível confiar. Dito por outras palavras, a confiança depende da possibilidade de supor o futuro obedecendo a regras não radicalmente distintas das do passado e do presente. A regularidade é uma condição de possibilidade da confiança. Ora, "«confiar» é muito simplesmente a condição nativa do espírito", escreve Fernando Gil no seguimento de Wittgenstein. ${ }^{126}$ A confiança não se exercita apenas no plano da comunidade, no plano ético ou político das relações interpessoais, embora se trate obviamente de algo de fundamental: a confiança que os cidadãos depositam, ou não, no governo, na justiça, etc. Ela joga (como Hume o viu perfeitamente: o problema da indução é, em parte, um problema de confiança) igualmente um papel decisivo do ponto de vista cognitivo. Devo confiar no conhecimento e na minha capacidade de conhecer. A liquidação da confiança do ponto de vista cognitivo - tal como do ponto de vista político ou moral ("perder a confiança" em alguém) - é tendencialmente desastrosa. A própria expressão "perder a confiança" aponta para uma certa derelição, para um isolamento e abandono, que é intuitivamente apercebido como quebra de continuidade. No Grande Sertão, de Guimarães Rosa, Riobaldo diz que "a gente vive, eu acho, é mesmo para se desiludir e se desmisturar". É uma parte da verdade, sem dúvida. Mas Timão de Atenas não é um cidadão exemplar, a tomar como modelo. E a desconfiança de princípio nas ciências é inibidora de todo o conhecimento. Pelo contrário, a confiança "revela-se um fator de inteligibilidade e contribui assim para o êxito da empresa do conhecimento". ${ }^{127}$ Uma espécie de virtù epistémica, poder-se-ia dizer. Uma virtù epistémica com reflexos epistemológicos. Porque, nas ciências da natureza, lidamos "com uma esfera objetiva desde a origem impenetrável à razão" (Hermann Weyl). ${ }^{128}$ Por isso mesmo é necessário confiarmos na possibilidade de vencer essa impenetrabilidade. É a confiança - a começar pela confiança em certas crenças fundamentais e inabaláveis, crenças não fundadas sobre as quais se erigem as crenças fundadas (é o Wittgenstein de Sobre a

\footnotetext{
124 A conviç̧ão, p. 43.

125 A convicção, p. 226.

126 A convicção, p. 192.

127 A convicção, pp. 43-44.

128 A convicção, p. 15.
} 
certeza que aqui é convocado ${ }^{129}$ - que nos permite avançar no conhecimento e na sua "validação progressiva". ${ }^{130} \mathrm{E}$ é também ela que nos permite agir: "A confiança não releva da psicologia, diz respeito à ontologia da ação. É também um pressuposto da inteligibilidade, uma vez que as construções participam do registo do ato". 131

É importante voltar à questão do tempo, da qual, de resto, nunca verdadeiramente saímos, para a determinar com mais exatidão. Ela encontra-se, temo-lo visto, no cerne do problema da convicção. "Muito mais fortemente do que a crença, a convicção prende-se com a temporalidade". ${ }^{132}$ Podemos, segundo Fernando Gil, que retoma uma tese importante de McTaggart (The Nature of Existence), determinar duas séries temporais. A primeira diz-se: passado/presente/futuro; a segunda é a série do antes e do depois. ${ }^{133}$ A série passado/presente/futuro desenha-se como uma linha contínua, e é vivida como tal pelo sujeito. O presente prolonga o passado, e o futuro prolonga o presente, por uma "duração indeterminada". Não há, nesta série, qualquer quebra de continuidade. $\mathrm{O}$ mesmo não acontece com a segunda série. Antes e depois (de Cristo, por exemplo) remete para factos objetivos, independentes do sujeito. Como Fernando Gil escrevia já em Mimésis e negação, onde havia pela primeira vez analisado esta distinção: "A segunda das séries é impessoal e refere-se exclusivamente à situação objetiva", e "«antes-depois» não se desloca ao longo do eixo do tempo [...] Nesta série os acontecimentos são colocados absolutamente". ${ }^{134}$ Do ponto de vista que nos interessa aqui, a primeira série possui relações com aquilo que Fernando Gil, no seguimento de Fichte, designa por duração (já a encontramos); a segunda, com aquilo que o mesmo Fichte chama sucessão. ${ }^{135}$ Esta distinção é importante e repercute-se de diversas maneiras.

Sem a pretender analisar em detalhe aqui, visto ser extremamente complexa a articulação das duas séries, limitemo-nos a assinalar um ponto preciso. A duração, tal como a existência, vimo-lo, é, pelo menos em parte, o produto de um ato da imaginação, da "virtude realizante da imaginação". ${ }^{136}$ Já referi antes que é a imaginação que "fabrica a continuidade". Duração e continuidade significam praticamente o mesmo: a duração é a tradução temporal da

\footnotetext{
129 A convicção, p. 192.

130 A convicção, p. 69.

131 A convicção, p. 41. Cf. tb. A convicção, p. 43.

132 A convicção, p. 226.

133 A convicção, p. 42.

134 Mimésis e negação, p. 19.

135 Sobre a relação entre sucessão e duração, $c f$. $A$ convicção, pp. 225 e ss.

${ }^{136}$ A convicção, pp. 17, 44, 59, 60.
} 
continuidade. "A duração é obra da crença e da imaginação". ${ }^{137}$ Ela "resulta da flutuação inconsciente da imaginação entre o Eu e o Não-Eu". ${ }^{138}$ (Não me deterei também aqui no detalhe desta "flutuação".) Ora, o mesmo não acontece com a sucessão: "A sucessão não nasce da flutuação da imaginação, mas do querer e da prática". ${ }^{139}$ Mas o querer e a prática "não são menos originários e irredutíveis do que a imaginação", 140 e a "compacidade originária da duração" convive com a "descontinuidade igualmente originária da sucessão". ${ }^{141}$ Temos pois dois regimes de temporalidade igualmente originários mas perfeitamente distintos. Um, a duração, produto da imaginação; outro, a sucessão, efeito da prática. Sendo identicamente originários, não há maneira de fazer um derivar do outro. Podemos apenas estabelecer passagens entre ambos. E reconhecer que um e outro se revelam instrumentais para as operações que engendram a convicção. É verdade que uma solução tentadora, e na linha do que temos visto, seria sugerir que a sucessão (e a série do antes/depois) aparece como uma reificação (alucinatória) da duração (e da série passado/presente/futuro). Esta segunda apresenta, com efeito, uma fluidez que a outra não contém. A sucessão introduziria a descontinuidade, e com ela elementos discretos -27 de fevereiro de 1970, por exemplo - que seriam o protótipo mesmo da reificação: é o próprio da cronologia, por oposição à temporalidade viva (autêntica, eigentlich, diria Heidegger). E assim se reconduziriam os dois regimes de temporalidade aos dois "regimes de inteligibilidade" 142 que são a fundação e o fundamento: a sucessão ocultaria a duração. $O$ mais fácil é admitir que nos encontramos aqui face a uma das múltiplas metamorfoses dessa aporia fundadora, não só da matemática, como afirmou René Thom, mas de praticamente todas as disciplinas: a oposição entre contínuo e discreto. (Em sociologia, por exemplo: indivíduo/sociedade; individualismo metodológico/holismo; Weber/Durkheim, etc.) Parece ser, de resto, essa a posição de Fernando Gil, que salienta tanto a diferença entre os dois regimes como as passagens entre eles. Como se liga a sucessão à duração?, pergunta ele. ${ }^{143}$ "A sucessão e a duração não se deixam pensar juntamente". ${ }^{144}$ Por um lado, temos "a causalidade do querer, por via da sucessão" (a origem da sucessão é "o meio ambiente do querer"); por outro, "a imaginação flutuante, reversível, que nessa medida

\footnotetext{
${ }^{137}$ A convicção, p. 226. Cf. tb. A convicção, p. 43.

138 A convicção, p. 228.

139 A convicção, p. 229.

${ }^{140}$ A convicção, p. 229.

141 A convicção, p. 234.

142 A conviç̧ão, p. 95.

${ }^{143}$ A convicção, p. 226.

144 A convicção, p. 228.
} 
dura". ${ }^{145}$ "Nenhuma medida comum une a duração reversível que emerge da flutuação da imaginação e a sucessão irreversivel na qual se realiza a vontade causal do eu". ${ }^{146}$ A sucessão baseia-se na "intuição vivida das operações" e a duração "é obra da crença e da imaginação", já o sabemos. Mas, "embora as estruturas temporais da crença e da intuição sejam diferentes, não é possivel dissociá-las por completo". ${ }^{147}$ É verdade que o querer e a prática instituem a sucessão, e que é nesta que se produz a evidência: "No tempo do fazer a evidência é direta". ${ }^{148} \mathrm{E}$ : "A intuição direta das construções decorre, sem mais, da natureza do fazer, a sua inteligibilidade resume-se à apreensão de cada elemento ou de cada etapa de uma operação, e do produto desta". ${ }^{149}$ Ainda: "a sucessão é homóloga da consciência temporal fragmentada concomitante das etapas da construção". ${ }^{150}$ Mas a sucessão depende de algum modo da duração: "A atividade gera a sucessão temporal mas pressupõe o tempo unido, fluente e retencional da duração, do qual depende também a compreensão"."151 Ou, noutros termos: "O esquema do fazer convoca a duração". ${ }^{152} \mathrm{~A}$ "intimidade do espírito" necessária à inteligibilidade das construções e das operações - que são, como se viu, obtidas na sucessão pelo querer e pelo fazer - "pressupõe a duração, já que a intimidade depende de um sentimento de pertença que supõe um sujeito permanente". ${ }^{153}$ Mas este mesmo investimento da vontade na duração - a domesticação da duração pela vontade - confirma a exterioridade das duas séries. ${ }^{154}$ Os dois "regimes de temporalidade" são distintos. ${ }^{155} E$ é isso que devemos aceitar, mesmo que haja a possibilidade de uma explicação para a articulação das duas séries, ${ }^{156}$ que não referirei aqui. O que devo referir é que a sugestão anteriormente feita, segundo a qual a duração se encontraria do lado da fundação e a sucessão do lado do fundamento, ocultando a primeira, por apetecível que seja, não é válida. E não é válida porque a série da sucessão não coincide exatamente com a do antes/depois - ou, pelo menos, não se identifica com o solo fundador da cronologia - e porque é na sucessão - apoiada, é verdade, misteriosamente na duração - que se dá, de facto, a evidência, que,

\footnotetext{
145 A convicção, pp. 228-229.

146 A convicção, p. 229.

147 A convicção, p. 226.

148 A convicção, p. 227.

149 A convicção, p. 227.

150 A convicção, p. 227.

151 A convicção, p. 226.

152 A convicção, p. 226.

153 A convicção, p. 227.

154 A convicção, p. 229.

155 A convicção, p. 230.

156 Cf. A convicção, p. 236.
} 
essa sim, se encontra indiscutivelmente do lado da fundação, da convicção e da verdade.

Seja como for, é a imaginação que permite a crença na objetividade, uma crença que se dá no contexto da contingência ontológica de um mundo pré-constituído ${ }^{157}$ - isto é, de algo que se encontra já face a nós sem que disso sejamos responsáveis -, e que se desdobra na crença no princípio de razão - nada existe sem uma razão -, entendido como princípio da causalidade: a "exigência de causalidade" é a "modalidade científica do princípio de razão". ${ }^{158} \mathrm{O}$ conhecimento científico instaura-se por inteiro sobre esta tradução causal do princípio de razão, acrescentando-lhe o requisito de localidade: "A explicação científica reúne causalidade e localidade" (velha lição de René Thom). ${ }^{159}$ Quer dizer: a inteligibilidade máxima é sempre oferecida pela explicação mecânica através do choque (daí as sabidas relutâncias do próprio Newton em admitir a ação à distância: não por razões que se prendessem com o conservadorismo da "ciência normal" kuhniana, mas por bons e simples motivos de inteligibilidade). A exigência de localidade prende-se com isto. "Compreendemos tão-só o finito, o discreto, o local, a propagação por contacto". ${ }^{160} \mathrm{O}$ conceito thomiano de pregnância - "uma causalidade agente apreendida intuitivamente" 161 - é "a versão «compreensiva», fundadora, da razão suficiente". ${ }^{162}$ A pregnância designa a própria eficiência da causalidade. As pregnâncias representam influências daquilo que Thom chama "saliências" (que são entidades discretas - como as bolas de bilhar ou os políticos, por exemplo) umas nas outras: "As pregnâncias, abertas, transportam-se através de um meio para investir formas salientes locais - indivíduos fechados - produzindo-se nelas transformações cinéticas ou morfológicas às quais Thom dá o nome de «efeitos figurativos»" ". ${ }^{163}$ Versão "compreensiva" do princípio de razão suficiente, ela indica o estrato mais originário que este oculta (como o fundamento oculta a fundação): remetendo-nos para a intuição, remete-nos igualmente para a ação fundadora da imaginação. É exatamente a força das pregnâncias que conduz a imaginação à crença, e esta à convicção e à objetividade. A validade objetiva das nossas representações repousa, com efeito, em

157 A convicção, p. 47.

${ }^{158}$ A conviç̧ão, p. 77. Sobre o princípio de razão, na sua relação ao fundamento, $c f . A$ convicção, pp. 101 e ss.

159 A conviç̧ão, p. 107.

160 A conviç̧ão, p. 107.

161 A convicção, p. 96.

${ }^{162}$ A convicção, p. 17. Sobre a relação entre causalidade e pregnância, $c f$. A convicção, pp. 105 e ss.

163 A convicção, p. 106. 
última instância na crença: "O conhecimento teórico assenta na crença", como escreve Hermann Weyl. ${ }^{164}$

$\mathrm{Na}$ produção dos objetos de conhecimento, o espírito manifesta uma "intencionalidade coisificante inconsciente". ${ }^{165} \mathrm{E}$ nisso não depende da perceção: os objetos são afirmados - postos - independentemente dos dados percetivos. "A operação da crença reside nessa produção irresistível de um não-eu, que a simples perceção por si mesma não é capaz de realizar". ${ }^{166}$ Quer dizer: a simples perceção não é a causa da afirmação da exterioridade: é a própria posição que o espírito efetua que a produz. A doutrina fichteana do sentimento (que já abordámos) relaciona-se assim com a posição da exterioridade. ${ }^{167}$ É através do sentimento que concluímos acerca da existência de algo de existente fora de nós. ${ }^{168}$ A perceção, "a primeira construção da experiência", ${ }^{169}$ representa a face objetiva do sentimento, ${ }^{170} \mathrm{o}$ sentimento a face interna da perceção. ${ }^{171} \mathrm{O}$ par perceção-percecionado é "a metáfora do começo da prova de força, permanente e interminável, entre o sujeito e o mundo". 172 Para Fichte, que Fernando Gil segue também neste passo, o pensamento, vale a pena repeti-lo, objetiva por si mesmo: a construção da objetividade não se faz (contrariamente ao que defendia Husserl) a partir da evidência percetiva. ${ }^{173}$ A operação da crença reside na produção irresistivel do Não-Eu, na produção de objetividades, ${ }^{174}$ "movimento de objetivação" esse que é a "atividade real" do Eu. ${ }^{175}$ "A intuição das práticas faz-se acompanhar pela crença nas entidades, o movimento de objetivação cristaliza-se em objetividades". ${ }^{176} \mathrm{E}$ a crença revelará uma adesão aos objetos produzidos que é fundamental, uma espécie de projeção da originária adesão a si do sujeito: "A adesão transfere-se para o objeto da crença no modo da aspiração, do desejo, da satisfação". ${ }^{177}$ A questão

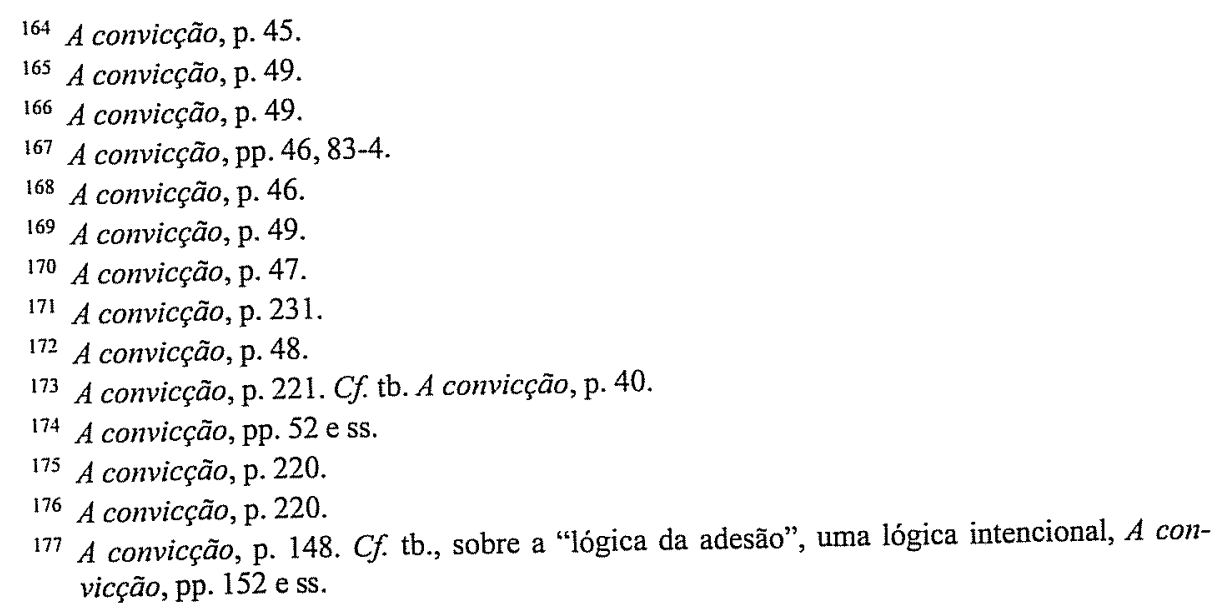


ontológica e a questão epistemológica, nota Fernando Gil, encontram-se assim ligadas. ${ }^{178}$ Existência e conhecimento dão-se conjuntamente.

A crença no Não-Eu confunde-se com a crença na existência. Salientam-se deste modo os laços que ligam crença e imaginação, a solidariedade arcaica que as une. "A crença na existência é anterior à consciência, já que o trabalho da imaginação releva da atividade espontânea da mens". ${ }^{179}$ Revisita-se aqui aquilo que já foi anteriormente dito em relação à pré-representatividade e à pré-reflexividade da crença. De facto, de uma certa maneira, a crença é cega, pré-reflexiva. "A energia da crença investe-se diretamente, sem reflexão, no conteúdo". ${ }^{180}$ Obedece ao princípio fichteano da projectio per hiatum. ${ }^{18 \mathrm{I}}$ Quer dizer: atravessa, sem pestanejar, abismos. Investe a sua força própria em qualquer objeto. Literalmente: pode-se acreditar em tudo, desde que se aceite o que se acredita como verdadeiro.

De facto, acreditar no Não-Eu é acreditar no real, na verdade. "Verdade da crença e crença no real confundem-se". ${ }^{182}$ Por isso, é possível falar de uma assimetria entre o verdadeiro e o falso, ${ }^{183} \mathrm{de}$ um "primado do verdadeiro sobre o falso". ${ }^{184}$ Não podemos, pura e simplesmente, acreditar naquilo que pensamos ser falso. ${ }^{185}$ Tal resultaria em algo ainda mais profundo do que aquilo que KarlOtto Apel chamou "auto contradição performativa": uma auto contradição epistémica, pré-discursiva, e, no limite, uma impossibilidade ontológica. "Verdade e crença caminham juntas". ${ }^{186} \mathrm{O}$ verdadeiro - cuja "marca fundamental [...] reside na sua evidência" 187 -, é, como pretendia Espinosa (e, de um certo modo, também Wittgenstein), ${ }^{188}$ a norma do verdadeiro e do falso. ${ }^{189}$

Passando da crença à convicção, podemos dizer que esta - que não se confunde com o "sentimento subjetivo da certeza", 190 o mero "atestado subjetivo da verdade" 191 como coisa exterior ao sujeito - é "o modo subjetivo do

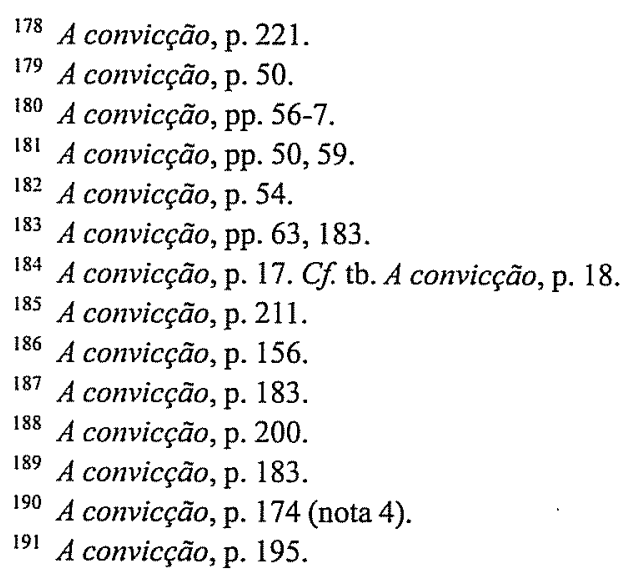


verdadeiro". ${ }^{192}$ "Estar convencido significa saber o verdadeiro". ${ }^{193}$ É "saber" que aqui é importante, na diferença que mostra por relação à crença: o saber implica operações, construções. Várias citações: "Há um círculo da convicção e do verdadeiro. Só do verdadeiro se está autenticamente convencido, e só o verdadeiro força a convicção" ${ }^{194}$ "Verdade e convicção articulam-se, não há convicção sem verdade e não há verdade sem convicção". 195 "A força da convicção atrai para si, se assim se pode dizer, o objeto possível da crença". ${ }^{196}$ Finalmente, a convicção participa do "amor do verdadeiro". ${ }^{197}$ Tal amor permite-nos associar convicção e felicidade, a convicção da verdade traz consigo a felicidade. ${ }^{198}$ Reaparecimento de um tema constante na obra de Fernando Gil: a "satisfação intelectual", o "preenchimento" das "expectativas", etc. 199

É a altura de voltar ao par fundamento/fundação, já anteriormente referido, e tendo em conta os desenvolvimentos posteriores. Fundamento e fundação representam "dois regimes de inteligibilidade distintos". ${ }^{200} \mathrm{O}$ pensamento do fundamento distingue-se do pensamento da fundação, como já foi dito, a atividade fundacional é coisa diversa do fundamento. E este último encobre-a. "O fundamento da ciência encobre os atos de fundação e a vontade que se encontra na sua origem" ${ }^{201}$ recalca a fundação. ${ }^{202} \mathrm{O}$ pensamento do fundamento oblitera a atividade, o agir, que se encontra no coração da fundação: é nisso que reside a ideologia. $\mathrm{E}$, por isso mesmo, o fundamento não assegura a inteligibilidade máxima que só na fundação se encontra. E só nela se encontra porque só nela a ação do Eu é completamente transparente a si própria e a "experiência própria", qualitativa, sem a qual a compreensão não se produziria nunca, se verifica. Só o pensamento da fundação se dá na imanência (o fundamento põe sempre, por definição, uma transcendência). Só ele garante a confiança epistémica, e quase ontológica, necessária à ação. É apenas na fundação que a inteligibilidade da pregnância (versão compreensiva, como se disse, do princípio de razão) se dá a ver e que são compreensiveis as operações

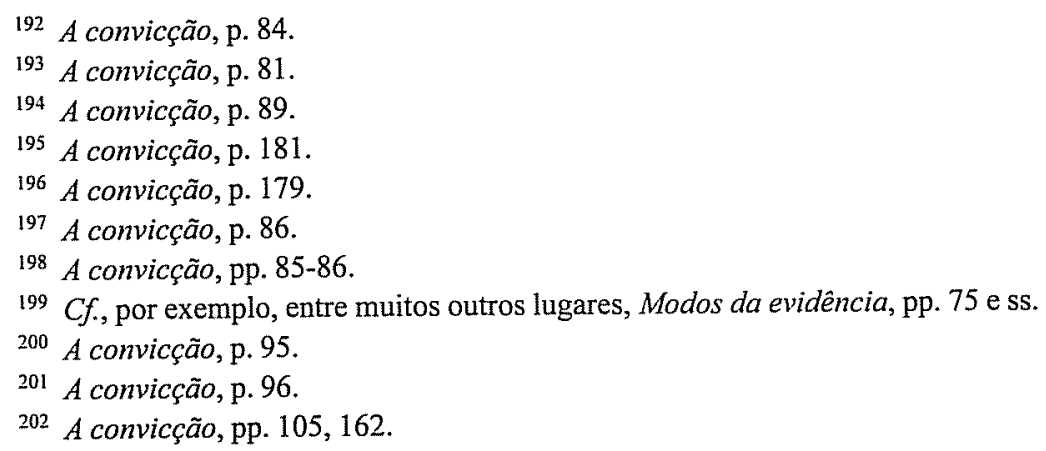


que subjazem à posição da exterioridade. Verdade e convicção encontram-se, de facto, do lado do pensamento da fundação.

Um exemplo. O operador essencial do pensamento do fundamento é o operador 'Nada de maior", ${ }^{203}$ o princípio da ilimitação já atrás referido, que Fernando Gil encontra em Santo Anselmo, ${ }^{204}$ Bodin ${ }^{205}$ e Hobbes, ${ }^{206}$ bem como em Grócio e Pufendorf. ${ }^{207}$ Tal operador é um operador de existência. Ele precipita o infinito no singular. Como escreve Fernando Gil a propósito da prova anselmiana da existência de Deus no Proslogion: "A concentração do infinito no indivíduo precipita a razão na existência: a existência de Deus aparece como a consequência evidente da fusão do singular com um operador de infinito". ${ }^{208} \mathrm{O}$ mesmo investimento do infinito num só indivíduo se encontra na teoria da soberania de Hobbes. ${ }^{209}$ "Aquilo que é próprio à crença [...] é pôr a existência". ${ }^{10}$ Mas a existência é, no limite, "impensável". ${ }^{211}$ A crença na existência não equivale a uma convicção da existência. "Porque é que a minha alma não te sente, Senhor Deus, apesar de te ter encontrado?", pergunta Santo Anselmo. ${ }^{212}$ Porque não se passa necessariamente da crença à convicção, como o fracasso da prova ontológica mostra à evidência. A alucinação anselmiana falha, como se disse atrás. Não há maneira de determinar convenientemente os seus objetos, a apropriação subjetiva do conhecimento não se deixa perfazer por inteiro. Falta a "experiência própria", o quale. Nenhuma intuição se apresenta, indesmentivel. O pensamento do fundamento pode, no limite, persuadir (é essa a função da ideologia): mas não pode, de maneira alguma, convencer. Deste modo, há também uma assimetria entre convicção e crença, paralela - se bem que, obviamente, não idêntica - àquela existente entre o verdadeiro e o falso: "A convicção compreende a crença [...] O inverso não é verdadeiro, a crença não implica a convicção". ${ }^{213}$

A fundação, como coisa distinta do fundamento, liga-se à atividade de construção, ${ }^{214}$ e é a construção que, ao mesmo tempo que exibe uma liber-

\footnotetext{
203 A convicção, p. 138.

204 A conviç̧ão, pp. 130, 137 ss.

205 A convicção, pp 118, 131.

206 A convicção, pp. 118-119, 130.

207 A convicção, p. 130.

208 A convicção, p. 138.

209 A convicção, p. 134.

210 A convicção, p. 148.

211 A convicção, p. 139.

212 A convicção, p. 140.

213 A convicção, p. 179.

214 A convicção, pp. 15, 19.
} 
dade essencial, permite a compreensão. ${ }^{215}$ Com a construção, passamos da crença à convicção. Passamos para o domínio de uma "atividade cognitiva" que é "transparente a si mesma", onde nada se coloca como um obstáculo entre sujeito e cognição. ${ }^{216} \mathrm{E}$ não há obstáculo porque a cognição é inteiramente o produto das operações do sujeito. Vale a pena insistir de novo num aspeto, porque ele ilustra a força da construção - ou do que, à falta dela, the faz a vez: a vontade. $O$ fundamento não consegue nunca ocultar por completo a fundação. Mesmo que a "constituição da teoria aristotélica dos primeiros princípios, tal como a da soberania" proceda "de um recalcamento da fundação pelo fundamento", ${ }^{217}$ o noûs aristotélico "age como uma instância de presentificação e de construção", 118 é uma "instância de fundação", 219 "princípio de atividade e de construção", ${ }_{220}$ através dele "a atividade cognitiva apropria-se dos objetos intuindo as suas próprias construções".221 Do mesmo modo, se as tentativas de Anselmo para provar racionalmente a existência de Deus falham, elas exibem a alucinação (a distinguir de "ilusão") 222 na origem do fenómeno da crença ${ }^{223} \mathrm{e}$ a vontade que lhes subjaz. Finalmente, as "marcas da soberania" em Bodin ${ }^{224}$ deixam-se ler como a expressão da vontade de fundar o poder político unicamente em si mesmo:225 "A soberania realiza uma transcendência na imanência". ${ }^{226} \mathrm{~A}$ ocultação da fundação pelo fundamento - a ideologia, ao fim e ao cabo - falha exatamente porque acaba sempre por mostrar um princípio de atividade na sua origem: um princípio de atividade que remete, em última análise, para a vontade. ${ }^{227}$ Dito ainda de outra maneira: o fundamento deixa sempre ver as construções - as "cascas de ovo", diria Wittgenstein - de que se serviu para afirmar o objeto. $O$ tema da construção - que Fernando Gil desenvolve sobretudo a partir do intuicionismo matemático (incluindo Wittgenstein) - é um dos temas fundamentais deste livro, e encontra-se no centro de tudo o que ele nos diz sobre a inteligibilidade. Repita-se: "A atividade cognitiva apropria-se dos objetos intuicionando as suas

\footnotetext{
215 A convicção, p. 207.

216 A convicção, p. 189.

217 A convicção, p. 155.

218 A convicção, p. 155.

219 A convicção, p. 169.

220 A conviç̧ão, p. 169.

221 A convicção, p. 164.

222 A convicção, p. 95.

${ }^{223}$ A conviç̧ão, pp. 137, 146.

224 A convicção, p. 118.

225 A conviç̧ão, p. 116.

226 A convicção, p. 116.

227 A convicção, p. 105.
} 
próprias construções". ${ }^{228}$ A inteligibilidade depende da posse das criações do espírito pelo próprio espírito, da "intuição vivida das operações" ${ }^{229}$ que executam a passagem do determinável ao determinado ${ }^{230}$ (passagem que é igualmente o "solo transcendental da temporalidade", ${ }^{231}$ mas deixaremos esta questão de fora). A determinação efetiva (não ideológica) é uma construção que traz consigo a compreensão. Construção, inteligibilidade, compreensão, dizem-se umas às outras no que o sujeito faz: "Salvo dúvida hiperbólica, tenho a certeza de intuir tal qual o objeto que construo. As construções exibem-se sem deformação. Não podemos não estar certos do que nós próprios fazemos, a atividade é compreendida pelo agente". ${ }^{232}$ Compreensão e confiança vão uma com a outra: "A confiança nas construções das quais somos os agentes é um dado primitivo". ${ }^{233} \mathrm{E}$ devem ser buscadas no gesto atual do conhecimento: "A compreensão deve ser procurada na atualidade do conhecimento". ${ }^{234}$ "Atualidade" é aqui uma palavra importante: reenvia não só para "presencialidade" (um dos temas importantes da vertente fenomenológica do intuitus cartesiano) como também para "atuar", "agir". A convicção manifesta-se como "uma passagem ao ato" ${ }^{235}$ que é uma progressão, a atividade é o seu modo natural: "A compreensão de um conteúdo de conhecimento obtém-se através de atividades de construção efetuadas por um espirito que ajuíza, à medida que as executa, acerca do seu grau de validade" ${ }^{236}$ (a "validação progressiva" atrás referida). Tal progressão revela, como era pedido desde o início, como condição efetiva de racionalidade, uma intuição, e o tema da apropriação ressurge: "A apropriação da verdade deixa de ser um ideal da razão e torna-se um facto intuitivo incorporado no sujeito". ${ }^{237} \mathrm{O}$ acesso deste às suas próprias operações é indiscutível: "A ação da inteligência é imediatamente acessível ao sujeito". ${ }^{238}$ O sujeito descobre a verdade no seu agir, que é igualmente um construir imanente: "O agir experimenta-se na sua imanência ao sujeito". ${ }^{239}$ Fernando Gil salienta, como, creio, ninguém antes dele o fez (com a possível exceção de Hermann Weyl, mas este certamente de uma forma muito menos sistemática),

\footnotetext{
${ }^{228}$ A convicção, p. 164.

${ }^{229}$ A convicção, p. 226.

230 A convicção, p. 226.

231 A convicção, p. 234.

232 A convicção, p. 227.

${ }^{233}$ A convicção, p. 194.

${ }^{234}$ A convicção, p. 185

${ }^{235}$ A convicção, p. 200.

${ }^{236}$ A convicção, p. 186.

237 A convicção, p. 186.

${ }^{238}$ A convicção, p. 81.

${ }^{239}$ A convicção, p. 223.
} 
a continuidade entre Fichte e as teses intuicionistas. "A apropriação subjetiva pertence à própria ideia do saber". ${ }^{240} \mathrm{E}$ : "A compreensão não é senão essa reconstrução pessoal de um conteúdo de conhecimento". ${ }^{241}$

A construção permite a "certeza da certeza" - tema espinosiano que Fernando Gil aproxima da "convicção propriamente dita" de Wittgenstein, adquirida no exercício da demonstração e distinta da "certeza de primeira ordem", que "corresponde à proposição demonstrada" "242 -, ela conduz à "apreensão subjetiva do verdadeiro", 243 à "posse subjetiva da verdade". ${ }^{244} \mathrm{~A}$ "certeza da certeza", uma "certeza de segundo grau", ${ }^{245}$ é a convicção. Ela é "a certeza de conhecer (scire) epistemicamente a verdade". ${ }^{446} \mathrm{~A}$ "passagem" - uma passagem que é um ato - "da certeza à certeza da certeza faz-se no interior do espírito". ${ }^{247}$ Mais uma vez podemos observar a introdução do "sujeito epistémico [...] na teoria do conhecimento". ${ }^{248}$ Uma introdução que revela uma longa cadeia de operações do espírito na constituição da objetividade e na determinação dos objetos.

ABSTRACT

Fernando Gil's last philosophy, as exemplified in The Conviction, deals with the distinction between belief and conviction, as well as with the common features they both share. Such distinction relates to other distinctions: ground and foundation, ideology and truth, etc. Fernando Gil's main aim is the explanation of the intricate connections between the epistemic and the epistemological levels, that is between the relations the subject entertains with his beliefs and the relations those beliefs entertain with reality. In other words: his enquiry deals with the place of the subject in knowledge.

\footnotetext{
240 A convicção, p. 192.

241 A convicção, pp. 214-215.

${ }^{242}$ A convicção, p. 200.

243 A convicção, p. 181.

244 A convicção, p. 182.

245 A convicção, p. 181.

${ }^{246}$ A convicção, p. 181.

247 A convicção, p. 185.

248 A convicção, p. 182.
} 